\title{
MANAJEMEN PEMBELAJARAN AGAMA MELALUI PEMBIASAAN SHALAT DHUHA DI SEKOLAH DASAR NEGERI MEGA ELTRA
}

\author{
Imroatul Fatihah \\ Jurusan Manajemen Pendidikan Islam, Fakultas Ilmu Tarbiyah dan Keguruan IAIN \\ Syekh Nurjati Cirebon \\ imroatulfatihah.mpi@gmail.com
}

\begin{abstract}
Islamic religious learning should not be merely delivering material, but also instilling values and implementing it. In fact, so far the learning of Islam in schools is more limited to knowledge, because it is not managed properly, so it does not change behavior. However, something different happened in State Elementary School Mega Eltra, learning of Islamic religion through the habituation of the dhuha prayer could already be carried out in good learning management, even in conditions of limited religious facilities. For this reason, this research was intended to reveal more about religious learning through the habituation of the dhuha prayer in the Mega Eltra State Elementary School. This research was descriptive qualitative. The instruments were indepth observation, in-depth interviews, and documentation. Data analysis was carried out through data collection, data reduction, data display, and data conclusions. The findings showed that principals and religious teachers plan religious learning through curriculum development and meetings. Religious learning through habituation of dhuha prayer in state elementary school Mega Eltra was carried out in good management. It was indicated by students' enthusiasm taking ablution and performing dhuha prayer. Dhuha prayer was held in Islamic Education subjects. Dhuha prayer was carried out by students of grades 2 to 6. However, the place of worship was inadequate. Regularly, evaluations were carried out at teacher meetings.
\end{abstract}

Keywords: practice, value, example

\section{A. Latar Belakang Masalah}

Shalat dhuha merupakan salah satu di antara shalat-shalat sunah yang sangat dianjurkan oleh Rasulullah Shalallahu 'Alaihi Wassalam. Banyak penjelasan para ulama, bahkan keterangan Rasulullah Shalallahu 'Alaihi Wassalam, yang menyebutkan mengenai berbagai keutamaan dan keistimewaan yang dimiliki shalat Dhuha bagi mereka yang melaksanakannya (Alim, 2008: 63). Sebagaimana yang kita ketahui, bahwa manusia pada dasarnya tidak hanya terdiri dari dimensi lahiriyah fisik dan psikis saja, melainkan juga dimensi batin dan juga spiritual. Untuk memenuhi kebutuhan fisik dan psikis saja, tidak serta merasa cukup dengan terpenuhinya kebutuhan-kebutuhan ini, tentunya hal ini akan menyebabkan ketidakseimbangan dalam diri kita, karena dengan cara seperti itu tidak dapat memenuhi kebutuhan kita secara keseluruhan. Oleh karena itu, salah satu keutamaan shalat dhuha adalah untuk memenuhi kebutuhan kedua dimensi diri tersebut.

Secara garis besar, ajaran agama Islam mengandung tiga hal pokok, yaitu 
aspek keyakinan (aqidah), aspek ritual atau norma (syari'ah), dan aspek perilaku (akhlak). Aspek keyakinan yaitu dimana suatu ikatan seseorang dengan Tuhan yang diyakininya. Aqidah Islam adalah tauhid, yang meyakini ke-Esaan Allah Subhanahu Wata'ala, baik Dzat maupun sifat-Nya. Aspek syari'ah yaitu aturan atau hukum yang mengatur hubungan manusia dengan Allah Swt., manusia dengan sesama manusia, dan manusia dengan alam. Sedangkan aspek akhlak yaitu aspek perilaku yang tampak pada diri seseorang dalam hubungan dengan dirinya, sesama manusia, dan di lingkungan sekitar.

Keberimanan seseorang seluruhnya diukur oleh hal-hal yang bersifat akhlaqi, termasuk shalat, sebab seseorang yang melakukan shalat dengan makna yang sebenarnya, akan efektif untuk merealisasikan tanha 'anil fakhsya' $i$ wal munkar' di mana dengannya akan tercipta masyarakat yang damai, aman dan harmonis. Indikasi bahwa akhlak dapat dipelajari dengan metode pembiasaan, meskipun pada awalnya anak didik menolak atau terpaksa melakukan suatu perbuatan atau akhlak yang baik, tetapi setelah lama dipraktekkan, secara terusmenerus dibiasakan akhirnya anak mendapatkan akhlak mulia.

Seperti yang telah dijelaskan di atas, bahwa shalat itu dibagi menjadi dua macam, yaitu: shalat fardlu dan shalat sunah. Shalat fardhu adalah shalat yang dilaksanakan wajib yakni lima waktu seperti shalat dzhuhur, ashar, maghrib, isya' dan shubuh. Sedangkan shalat sunnah ialah shalat yang hanya dikerjakan di luar shalat fardhu dan hukumnya sunnah. Pada dasarnya shalat sunah terdiri dari beberapa macam, namun, dalam penelitian ini, peneliti lebih mengkhususkan pada shalat sunah dhuha.

Shalat dhuha merupakan shalat yang dilaksanakan ketika fajar mulai terbit dari jam 07:00-10:00, hal ini sudah diterapkan di SD Negeri Melga Eltra yang pelaksanaanya sudah dimulai dari pukul 07:00-09:00 sesuai dengan mata pelajaran
Agama. Shalat Dhuha adalah shalat sunat yang dilakukan pagi hari antara pukul 07:00 hingga jam 10:00 waktu setempat. Jumlah roka'at shalat dhuha minimal dua rokaat dan maksimal dua belas roka'at dengan satu salam setiap dua roka'at. Menurut Rifa'i (1976: 83), shalat dhuha adalah shalat sunnah yang dikerjakan pada waktu matahari terbit/naik. Sekurangkurangnya pelaksanaan shalat dhuha adalah dua raka'at, empat raka'at, atau delapan raka'at. Waktu pelaksanaan shalat dhuha kira-kira matahari sedang naik setinggi kurang lebih 7 hasta (pukul tujuh sampai masuk waktu dhuhur).

Adapun pendidikan agama di sekolah-sekolah kurang dikelola dengan baik dan tidak melibatkan seluruh sivitas sekolah serta kepemimpinan kepala sekolah. Pendidikan agama kurang terencana, lebih terfokus pada penyampaian materi yang bersifat kognitif dengan kurang penekanan pada aspek penanaman nilai dan aksi yang nyata berupa praktek langsung. Akibatnya, pelajaran kurang memberikan efek positif pada perilaku baik para siswa. Fakta-fakta mengenai demoralisasi di kalangan para pelajar seperti kasus tawuran, bully, pergaulan bebas dan lain-lain tidak bisa dilepaskan dari pembelajaran agama yang belum memainkan perannya dalam membangun karakter yang baik pada diri siswa.

Akan tetapi ada hal yang berbeda yang terjadi di SD Negeri Melga Eltra. Berdasarkan penelitian awal tanggal 4-22 Juli 2018, melalui observasi dan wawancara, peneliti menemukan fakta yang ada di SD Negeri Melga Eltra, bahwa pembelajaran agama sudah cukup tertanamkan melalui shalat dhuha di SDN Mega Eltra banyak sekali siswa yang sangat antusias melakukan shalat dhuha maupun hanya saat mata pelajaran PAI, namun antusiasme para siswa tidak berbanding lurus dengan sarana tempat ibadah yang digunakan, karena di SDN Mega Eltra semua siswa memakai kelasnya masing-masing untuk melakukan 
shalat dhuha dengan keadaan yang kurang bersih. Untuk itulah penelitian ini perlu ditindaklanjuti untuk mengung-kap secara mendalam terhadap fenomena ini.

\section{B. Landasan Teori}

Manajemen pembelajaran merupakan berbagai upaya pengatur-an proses belajar mengajar untuk mencapai proses belajar mengajar yang efektif dan efisien. Manajemen program pembelajaran acapkali dinamakan dengan manajemen kurikulum dan pembelajaran (Bafadhal, 2004: 11).

Konsep manajemen apabila diterjemahkan dalam aktivitas pembelajaran, menurut Syaiful Sagala dimaknai sebagai suatu upaya dan tindakan kepala sekolah sebagai pemimpin instruksional di sekolah dan upaya ataupun tindakan guru sebagai pemimpin pembelajaran di kelas dilaksanakan sedemikian rupa untuk mendapatkan hasil untuk mencapai tujuan pembelajaran dan program sekolah.

Sementara itu shalat dhuha adalah shalat sunnah yang dikerjakan pada waktu matahari terbit/naik. Sekurang-kurangnya pelaksanaan shalat dhuha adalah dua raka'at, empat raka'at, atau delapan raka'at. Waktu pelaksanaan shalat dhuha kira-kira matahari sedang naik setinggi kurang lebih 7 hasta (pukul tujuh sampai masuk waktu dhuhur) (Rifa'i, 1976: 83).

Sedangkan menurut Shofia (2003: 50) bahwasannya shalat dhuha ialah sebagai shalat sunnah yang dikerjakan pada waktu matahari sepenggalah naik sekitar pukul 07.00 sampai waktu menjelang dhuhur. Dalam surat al-Dhuha sendiri dijelaskan bahwasannya ketika waktu matahari setinggi tujuh hasta naiknya dan demi malam apabila telah sunyi (gelap).

Shalat dhuha dilakukan pada hari antara jam 06.30 hingga jam 11.00 bilangan raka'atnya dua raka'at dan sebanyak-banyaknya delapan raka'at. Menurut Abu Jamin (1992: 84) bahwasannya setiap dua raka'at satu shalat shalat dhuha adalah shalat sunnah yang dilakukan seorang muslim ketika waktu dhuha. Waktu dhuha adalah waktu ketika matahari mulai naik kurang lebih 7 hasta sejak terbitnya (kira-kira pukul tujuh pagi) hingga waktu dhuhur. Shalat dhuha merupakan shalat sunnah yang dianjurkan oleh Nabi, bagi siap umatnya yang mengamalkan shalat sunnah dhuha dua raka'at pada pagi hari maka orang tersebut akan dicukupkan sampai sore. Shalat dhuha adalah shalat pada siang hari yang dianjurkan. Pahalanya disisi Allah sangat besar. Rasulullah saw biasa melakukannya, dan mendorong kaum muslimin untuk melakukannya. Beliau menjelaskan barang siapa yang shalat empat raka'at pada siang hari niscaya Allah mencukupinya pada sore harinya.

Menurut al-Mahfani (2008: 37), ada tiga makna filosofis dalam shalat dhuha, yaitu:

1. Perwujudan syukur kepada Allah

Salah satu cara manusia bersyukur kepada Allah ialah mentaatinya dengan rajin beribadah sunnah, seperti shalat dhuha. Mentaati perintah Allah itu hukumnya wajib dan menjauhi larangan Allah juga wajib. Melaksanakan shalat merupakan salah satu upaya dalam mewujudkan rasa syukur kepada Allah atas segala rahmat, nikmat dan karuniaNya yang telah diberikan kepada manusia. Dengan melaksanakan shalat salah satunya dapat meminimalisir terlena kita terhadap urusan duniawi, sehingga hidup terasa lebih bermanfaat.

2. Mengingat Allah dalam keadaan senang Selalu ingat atau dzikir kepada Allah dapat menumbuhkan sifat baik, yaitu kesadaran manusia akan adanya pengawasan Sang Pencipta dari bagaimana manusia bertingkah laku menjalankan kehidupannya di bumi. Dzikir dapat dilaksanakan salah satunya dengan shalat, karena shalat merupakan media utama untuk berdzikir kepada Allah Subhanahu Wata'ala.

3. Tawakal dan berserah diri kepada Allah sebagai pengatur rezeki 
Sangat dianjurkan meluangkan waktu untuk melaksanakan shalat dhuha ini, karena merupakan upaya bertawakal kepada Allah. Meminta rezeki yang terbaik untuk kehidupan dapat diungkapkan setelah melak-sanakan shalat dhuha. Tujuan Shalat Dhuha

1. Sebagai media pembelajaran

Menurut al-Hadadd (1998: 24), yaitu dikatakan sebagai media pembelajaran karena merupakan kegiatan untuk memperkenalkan siswa pada shalat dhuha dan mencetak siswa yang beriman dan bertaqwa berlandaskan spiritual di lingkungan pendidikan Sekolah.

2. Sebagai Penggunaan Praktek/ Demonstrasi

Hal ini dilaksanakan dengan mudah oleh siswa-siswi mengetahui tata cara shalat dhuha dari mulai berwudhu sampai berdo'a.

3. Posisi Shalat Dhuha dalam Proses Pembelajaran

a. Sebagai amal ibadah

Menurut al-Hadadd (1998: 26), shalat sunnah dhuha merupakan shalat sunnah yang dianjurkan atau sholat sunnah ghoiru muakkad, yang pelaksanaan shalat merupakan sebuah rutinitas yang dapat dilakukan kapan dan dimana saja oleh manusia yang akan menjalankannya. Dengan melaksanakan shalat sunnah dhuha ini secara tidak langsung manusia mengumpulkan pundipundi pahala sebagai amal ibadah di akhirat nanti.

b. Bagian ibadah sunnah Nabi

Shalat sunnah dhuha merupakan shalat sunnah yang sangat dianjurkan dan oleh Rasulullah saw pun dilakukan sebagai ibadah tambahan.

c. Bagian pengenalan shalat dhuha bagi siswa

Pengenalan shalat dhuha bagi siswa memang harus dilaksanakan, dengan siswa mengenal dan adanya motivasi untuk melaksanakannya, maka hal ini akan berdampak baik bagi siswa.

Sementara itu, kaitannya dengan pembiasaan shalat dhuha, dapat ditelusuri dari makna pembiasaan. Husna (2015: 11) menjelaskan bahwa secara etimologi, pembiasaan asal katanya adalah biasa, seperti sedia kala, sudah merupakan yang tidak terpisahkan dari kehidupan seharihari. Sehingga pembiasaan dapat diartikan dengan proses membuat sesuatu/seseorang menjadi terbiasa. Dalam kaitannya dengan metode pengajaran dalam pendidikan Islam, dapat dikatakan bahwa pembiasaan adalah sebuah cara yang dapat dilakukan untuk membiasakan anak didik berfikir, bersikap dan bertindak sesuai dengan tuntunan ajaran agama Islam. Metode pembiasaan adalah suatu cara yang dapat dilakukan untuk membiasakan anak berfikir, bersikap, bertindak sesuai dengan ajaran agama Islam. Metode ini sangat praktis dalam pembinaan dan pembentukan karakter anak usia dini dalam meningkatkan pembiasaanpembiasaan dalam melaksanakan suatu kegiatan di sekolah.

Hakikat pembiasaan sebe-narnya berintikan pengalaman. Pembiasaan adalah sesuatu yang diamalkan. Oleh karena itu, uraian tentang pembiasaan selalu menjadi satu rangkaian tentang perlunya melakukan pembiasaan-pembiasaan yang dilakukan di setiap harinya. Inti dari pembiasaan adalah pengulangan. Dalam pembinaan sikap, metode pembiasaan sangat efektif digunakan karena akan melatih kebiasaan-kebiasaan yang baik kepada anak sejak dini. Pembiasaan merupakan pena-naman kecakapankecakapan berbuat dan mengucapkan sesuatu, agar cara-cara yang tepat dapat disukai oleh anak. Pembiasaan pada hakikatnya mempunyai implikasi yang lebih mendalam daripada penanaman caracara berbuat dan mengucapkan.

$$
\text { Dalam bidang psikologi }
$$

pendidikan, teori pembisaan dikenal 
dengan istilah behavioristime yang dicetuskan oleh John B. Watson dan digerakkan oleh Burrhus Frederic Skinner, yang mengatakan bahwasannya behaviorisme memandang bahwa ketika dilahirkan, manusia tidak membawa bakat apa-apa. Manusia akan berkembang berdasarkan stimulus yang diterimanya dari lingkungan sekitarnya. Lingkungan yang buruk akan menghasilkan manusia buruk; lingkungan yang baik akan menghasilkan manusia baik. Pandangan ini berasumsi bahwasannya apa yang terjadi pada seseorang salah satunya yang menentukan adalah lingkungannya. (Sobur, 2013: 123).

Pembiasaan sebenarnya berintikan pengalaman, yang dibiasakan adalah sesuatu yang diamalkan. Pembiasaan menentu-kan manusia sebagai sesuatu yang diistemawakan, yang dapat menghemat kekuatan, karena akan menjadi kebiasaan yang melekat dan spontan agar kekuatan itu dapat dipergunakan untuk berbagai kegiatan dalam setiap pekerjaan dan aktivitas lainnya.

Pembiasaan dinilai sangat efektif jika penerapanya dilakukan terhadap peserta didik yang berusia kecil. Karena memiliki rekaman ingatan yang kuat dan kondisi kepribadian yang belum matang, sehingga mereka mudah terlarut dengan kebiasaan-kebiasaan yang mereka lakukan sehari-hari. Oleh karena itu, sebagai awal dalam proses pendidikan, pembiasaan merupa-kan cara yang efektif dalam menanamkan nilai-nilai moral ke dalam jiwa anak. Nilai-nilai yang tertanam dalam dirinya ini kemudian akan termanifestasikan dalam kehidupannya semenjak ia mulai melangkah ke usia remaja dan dewasa.

Manajemen pendidikan agama yang efektif, ditemukan di lingkungan sekolah yang memungkinkan semua peserta didik menunjukkan potensi mereka untuk mencapai tujuan yang sangat penting. Dalam menanamkan pendidikan nilai-nilai pendidikan agama pada diri peserta didik tentunya seorang guru dituntut untuk memperhatikan kepribadian peserta didiknya. Hal ini diperlukan agar peserta didik mampu memahami dan merasakan serta mengerjakan nilai-nilai yang berlaku dalam masyarakat kelak. Salah satu pendidikan agama yang dapat dilakukan adalah dengan membiasakan shalat dhuha berjama'ah. Shalat dhuha sebagai sarana agar dengan shalat dhuha seseorang mampu mengendalikan diri sehingga tidak melakukan perbuatan keji dan munkar, serta perbuatan yang dapat merugikan diri sendiri dan orang lain. Pengendalian diri ini pada akhirnya akan memunculkan suatu perilaku atau akhlak yang mulia bagi lingkungan dan orangorang di sekitarnya.

Dampak pembiasaan shalat dhuha terhadap pembinaan akhlak sangat baik terlihat pada perilaku produktif dalam pemanfaatan waktu, hormat, disiplin, murah hati, dan peduli sesama. Peserta didik dapat mengontrol emosi atau amarah, selain itu pikiran dan hati peserta didik juga menjadi lebih tenang, sehingga akan memperlancar proses belajar. Menahan amarah yaitu upaya menahan emosi, agar tidak dikuasai oleh perasaan marah terhadap orang lain.

\section{Metode Penelitian}

Jenis penelitian yang telah dilakukan oleh peneliti menggunakan penelitian deksriptif. Menurut Kurniawan (2018: 29-36) bahwasannya penelitian deskriptif ialah penelitian yang dilakukan untuk mengetahui nilai dari variabel mandiri, baik satu variabel atau lebih tanpa membuat perbandingan atau menghubungkan dengan variabel yang lain. Penelitian ini dilakukan di Jl. Sekar Kemuning Kelurahan Karyamulya, Kecamatan Kesambi, Cirebon. Populasi dalam penelitian ini adalah seluruh siswa di SDN Mega Eltra. Sampel dalam penelitian ini adalah seluruh siswa Kelas III di SDN Mega Eltra yang berjumlah 34 siswa. Dalam penelitian ini, digunakan Snowball Sampling. 
Peneliti melakukan observasi mendalam dan kemudian wawancara mendalam. Wawancara dilakukan kepada subjek penelitian yang akan memperkuat data mengenai temuan di sekolah yang menjadi permasalahan penelitian ini. Dimulai dari kepala sekolah, guru agama yaitu Ibu Wiwi Winarsih, guru-guru bidang studi yang lain, pedagang kantin yaitu Ibu Nemi (penjual bakso bakar), kemudian bertanya kepada siswa-siswa, kemudian setelah kami mengetahui kepada siapa data yang dapat terjawab mengenai masalah penelitian ini, kami melakukan wawancara kepada Pengurus Mushola, kemudian yang terakhir kami melakukan wawancara kepada DKM mushola selaku informan yang mengetahui lebih jelas tentang permasalahan penelitian kami.

Instrumen pengumpulan data menggunakan pengamatan men-dalam, wawancara mendalam, dan dokumentasi. Analisis data dilakukan dengan tahapantahapan, sesuai yang dinyatakan oleh Huberman (1992: 63), dilakukan dengan pengumpulan data, reduksi data, display data, dan konklusi data.

\section{Temuan}

1. Perencanaan Pembelajaran Agama melalui pembiasaan shalat dhuha

Pembiasaan shalat dhuha sudah diimplementasikan di Sekolah Dasar Negeri Mega Eltra sejak tahun ajaran 2015. Sebelum mengimplementasikannya, sekolah melakukan persiapan-persiapan untuk mendukung pelaksanaannya. Persiapan yang dilaksanakan sekolah untuk mendukung kesiapan pembiasaan shalat dhuha, yakni guru-guru dan kepala sekolah melakukan rapatrapat membahas penerapan shalat dhuha. Hasilnya adalah kesepatan bersama untuk menyusun kurikulumnya dan kerjasama serta dukungan semua pihak untuk mensukseskan pelaksanaan shalat dhuha bagi para siswa yang dicontohkan oleh semua guru.
Perencanaan pembelajaran agama melalui shalat dhuha disusun guru agama guna membantu berlangsungnya proses belajar mengajar menjadi efektif dan menyenangkan. Tahap pendahuluan perencanaan pem-belajaran sejalan yang tertera di dalam Permendikbud No 65 Tahun 2013 ialah menyusun silabus pembelajaran. Silabus adalah rencana dasar dalam pembelajaran yang dikembangkan menjadi RPP (Rencana Pelaksanaan Pembelajaran). Guru agama mengembangkan pokok bahasan materi selaras dengan kompetensi inti dan kompetensi dasar mata pelajaran. Dalam kurikulum ini, ia mengembangkan menjadi silabus dan RPP.

2. Penerapan pembelajaran agama melalui pembiasaan shalat dhuha di SDN Mega Eltra

Penerapan agama di SDN Mega Eltra terdiri dari beberapa penerapan. Penerapan agamanya sendiri diantaranya; pelaksanaan shalat dhuha di sekolah, dan terkadang untuk kelas atas seperti kelas 6 shalat dhuhur di sekolah. Penerapan agama di SDN Mega Eltra sudah berjalan kurang lebih 4 tahun untuk penerapan agama mengenai shalat dhuha.

Selain shalat dhuha, penerapan agama di SDN Mega Eltra juga selalu diadakan kegiatan rutin murajaah Surat-Surat Pendek (juz 30). Pelaksanaannya dilaksanakan setiap setelah selesai mata pelajaran Pendidikan Agama Islam (PAI). Siswa melafalkan ayat-ayat alQur'an secara bersama-sama dengan tidak memuka juz 'Amma atau alQur'an dan dipandu oleh guru agama. Teknis ruangannya sendiri, biasanya dilakukan di kelas atau di ruang perpustakaan yang juga difungsikan untuk tempat sarana ibadah shalat dhuha. 
Melalui shalat dhuha di SDN Mega Eltra sudah menjadi pembiasaan, hal ini terlihat dari sikap siswa-siswinya yang cukup antusias dalam melaksanakan shalat terutama shalat dhuha. Shalat dhuha merupakan salah satu program kegamaan, yang rutin dilaksanakan di SDN Mega Eltra. Shalat dhuha yang dilaksanakan di SDN Mega Eltra sudah sejak lama dilaksanakan, kurang lebih tiga tahun terakhir, yaitu pada tahun 2015 .

Pelaksanaan shalat dhuha dilaksanakan dua kloter, yaitu terkadang siswa laki-laki terlebih dahulu kemudian siswa perempuan. Namun pernah juga dilaksanakan bersama-sama (berjama'ah) diantara siswa, sebagaimana yang diungkapkan langsung oleh narasumber, guru agama, yaitu, "shalat dhuha di SDN Mega Eltra dilaksanakan bergantian, terkadang laki-laki terlebih dahulu kemudian perempuan. Karena ruangannya terbatas." (Narasumber Guru Agama Ibu Wiwi Wihartini, M.Pd., 15/11/2018).

Berdasarkan data dari wawancara dengan narasumber, awalnya, shalat dhuha memang tidak sengaja menjadi salah satu program sekolah dalam aspek keagamaan ketika rapat bersama kepala sekolah dan guru-guru, namun karena ketika guru agama di SDN Mega Eltra akan melaksanakan shalat dhuha. Kemudian, ada beberapa siswa yang bertanya kepadanya, lalu siswa tersebut mengikuti guru agama untuk melaksanakan shalat dhuha. Hal ini terjadi secara terus menerus, sehingga guru agama menerapkan program shalat dhuha ini sampai sekarang (2018) sebagai pembiasaan.

Pelaksanaan shalat dhuha di SDN Mega Eltra hanya seminggu sekali, dimana setiap kehadiran mata pelajaran agama saja.
Pelaksanaannya pun dimulai dari kelas 2 sampai 6. Alasan mengapa kelas I tidak dianjurkan dalam melaksanakan shalat dhuha ialah sebagai berikut ungkapan langsung dari guru agama dalam wawancara.
"Tadinya dari kelas I dilaksanakan pembiasaan shalat dhuha, tetapi kelas I itu ribet, siswa-siswinya masih belum bisa memakai sepatu, karena kalau shalat harus wudhu dulu, jadi sepatunya harus dibuka. Jadi ya dimulai dari kelas dua, karena kelas dua sudah lumayan bisa pakai sepatu sendiri." (Narasumber Guru Agama Ibu Wiwi Wihartini, M.Pd., 15/11/2018).

Guru agama memerintah-kan kepada siswa-siswinya untuk shalat dhuha terlebih dahulu sebelum kegiatan belajar meng-ajar (KBM) dimulai, namun terkadang pula setelah melaksana-kan kegiatan belajar mengajar (KBM). Bergantung jam pelajaran yang sudah tertera di setiap kelas. Misalnya, jadwal di kelas III pada jam 7.15 yang dilaksanakan shalat dhuhanya sebelum kegiatan belajar mengajar (KBM) sekitar pukul 7.15; dan pelaksanaan shalat dhuha yang dilaksanakan pada pukul 09.15 (ketika jam istirahat) untuk kelas yang kegiatan belajar mengajar (KBM)-nya setelah istirahat, seperti di kelas IV. Namun terkadang pula, baik kegiatan belajar mengajar (KBM) dilaksanakan awal jam yaitu 7.15, siswa-siswi melaksanakan shalat dhuha terlebih dahulu, bagaimana bergantung pada kemauan siswa dan guru.

Pelaksanaan shalat dhuha menjadi kendala ketika listrik mati, karena sekolah meng-gunakan PDAM dan Sanyo (menggunakan listrik). Ketika PDAM tersendat- 
sendat, dan Sanyo mati karena listrik mati, sehingga shalatnya cukup terhambat, namun guru memberi-kan solusi seperti ungkapan dalam wawancara.

"Ketika anak ingin shalat dan air tidak ada, PDAM tersendat, dan Sanyo tidak bisa nyala karena menggunakan listrik, Saya suruh siswa-siswi shalat-nya minggu depan lagi, karena kan airnya tidak ada, namun siswa-siswi tuh kekeh pengen shalat, katanya tayamum aja sih bu di tembok. Kata Saya, ya sudah tayamum. Siswa-siswi suka seperti itu, karena kan sudah biasa, sehingga kalau tidak shalat dhuha, seperti ada yang kurang. Walaupun ada syarat minimal-nya, namun untuk membang-kitkan semangat shalat dhuha anak, Saya membolehkan." (Narasumber Guru Agama Ibu Wiwi Wihartini, M.Pd., 15/11/ 2018).

Pelaksanaan shalat dhuha di SDN Mega Eltra dilaksanakan sudah baik, terlihat dari antusiasnya siswasiswi yang melaksanakan shalat dari mulai mengantri berwudhu dan melaksanakan shalatnya. Namun pelaksanaannya di kelas masingmasing, namun terkadang diruang perpustakaan. Ini dikarenakan semua ruangan di sekolah sudah tidak ada lagi tempat yang dijadikan sebagai mushola. Sebagaimana ungkapan guru agama dalam wawancara.

"Ketika itu sempat dijadikan mushola gudang yang tidak terpakai, dibersihkan, kemu-dian diberi karpet sebagai alas untuk shalat. Tetapi karena pintunya bolong, banyak tikus yang masuk ke dalam, siswa-siswi mengeluh karena bau dan banyak kotoran tikus dan kucing. Kemudian pindah ke perpustakaan, setelah dibereskan dan diberikan alas karpet baru bisa digunakan shalat dhuha. Namun karena ruang perpustakaannya terkadang dipakai oleh siswa kelas lain, jadi terhambat pelaksanaannya, sehingga memutuskan di kelas saja, daripada tidak shalat dhuha." (Narasumber Guru Agama Ibu Wiwi Wihartini, M.Pd., 15/11/2018).

Pelaksanaan shalat dhuha di SDN Mega Eltra memang sempat dimushola warga yang jaraknya sangat dekat (bersebelahan), namun sudah tidak dilaksanakan selama 2 bulan terakhir, karena mushola warga tidak boleh dipakai oleh siswa-siswi yang bersekolah di SDN Mega Eltra. Berikut beberapa informasi yang didapatkan dari salah satu penjual makanan dikantin sekolah, "dulu sih dipakai shalat dhuha oleh siswa, tetapi karena siswa-siswi wudhu disitu, lantainya jadi basah dan kotor, dan tidak dibersihkan pula. Warga juga sering mengeluh seperti itu." (Narasumber Ibu Nemi, penjual bakso bakar di kantin SDN Mega Eltra, /11/2018).

Berdasarkan ricek kami mengenai hal tersebut, bertanya langsung kepada guru agama, bahwasannya siswa tiba-tiba mengeluh kepada guru agama tidak bisa shalat dimushola karena terkunci. Kemudian, guru agama mencari tahu persoalannya kepada warga, ternyata dikarenakan mushola selalu kotor setelah dipakai shalat oleh siswa SDN Mega Eltra, padahal sudah menjadi pembiasaan setelah shalat guru memerintahkan untuk membersihkan dengan mengepel kembali lantai yang kotor, dibersihkan karpetnya, terkadang juga guru memerintahkan untuk mengelap jendela, dan siswa melaksanakannya. Apabila pekerjaan siswa membersihkan mushola tidak 
bersih, maka guru agama sendiri yang bertindak membersihkannya sehabis jam pelajaran ketika sebelum pulang. Berikut ungkapannya.

"Saya juga suka ngontrol bersih atau tidak, dan kalau tidak bersih sama Saya dibersihkan. Kalau alasan begitu, memang tidak pernah lihat Saya membersihkan mushola tah kalau persoalan-nya kebersihan. Warga juga nyapa ketika Saya membersih-kan. Alasan pertama mungkin mengenai kebersihan dan kemudian alasan kedua mungkin masalah air, padahal guru sebelum mushola itu belum punya PDAM, mereka minta ke SD (nyambung) karena dekat jadi bisa, dan tidak menyumbang dari pihak mushola, kurang lebih 2 tahun. Sekolah Mega Eltra hampir mengeluarkan uang 100-200 ribu untuk PDAM, namun sekolah sangat menerima, itung-itung shodaqoh. Lalu kalau alasannya air, waktu itu loh, kita sampai membela-bela mushola minta air ke sekolah dikasih, dan sekarang paling siswa wudhu paling beberapa liter air, kalau misalkan toh mau minta bayaran ya justru dibolehkan sebetulnya, tetapi mereka tidak pernah minta untuk soal air. (Narasumber Guru Agama Ibu Wiwi Wihartini, M.Pd., 15/11/2018).

Berdasarkan wawancara
dengan Pengurus Mushola alMawaddah bahwasannya mendapatkan data-data sebagai berikut:

"Sekarang ini memang tidak lagi digunakan, kenapa digembok menurut yang saya tahu karena siswa-siswi itu suka kotor memakai sepatu ke kamar mandi dan tidak dibersihkan. Mungkin kalau dibersihkan diperbolehkan shalat disini. (Narasumber
Pengurus Mushola al-Mawaddah Acep, 21/11/2018).

Berdasarkan wawancara dengan DKM al-Mawaddah bah-wasannya mendapatkan data-data sebagai berikut:

"Siswa-siswi SDN Mega Eltra sebenarnya bukan tidak diperbolehkan shalat di mushola, bukan berarti karena mushola bukan punya sekolah tapi punya warga. Boleh saja, sangat boleh bahkan mushola dipakai untuk shalat siswa, bahkan mukena dan sarungnya pun sudah banyak disimpan di mushola oleh anak-anaknya sendiri. Namun yang membuat Saya kurang setuju siswa shalat di mushola karena alasannya yang pertama dari segi kebersihannya suka tidak dibersihkan lagi, tiba-tiba kotor dan didalamnya berantakan sarung, mukena dan karpet. Jika alasannya dikunci karena Saya pernah lihat dari penjual makanan masuk ke kamar mandi mushola dengan tidak menjaga kebersihan, sehingga Saya gembok. Siswa kalau mau shalat boleh melewati gerbang yang selain gerbang samping yang terdapat orang berjualan (bisa dari depan mushola) asal syaratnya harus tetap bersih setelah wudhu, dan dirapikan lagi peralatan shalat dimasjid setelah digunakan." (Wawancara dengan DKM al-Mawaddah, Drs. Abdul Karim, M.Ag, 21/11/2018).

Shalat dhuha di ruangan kelas memang kurang kondusif dengan permasalahan tercipta-nya kebersihan tempat ibadah. Belum dengan selama proses pembelajaran siswa-siswi tetap menggunakan sepatu. Hal ini menjadikan peluang besar kelas yang menjadi tempat ibadah terdapat najisnya. Karena kita tidak tahu alas sepatu yang dipakai siswa telah menginjak apa saja ketika perjalanan dari rumah ke sekolah, dan belum lagi tidak 
setiap hari siswa mencuci sepatunya.

Berdasarkan pengamatan, ketika shalat dhuha, masih banyak siswa yang menaruh sepatunya dibawah meja yang masih kotor (banyak tanah berserakan di lantai). Sehingga hal ini mengundang adanya najis. Yang seharusnya dibiarkan ditaruh di luar kelas. Namun karena tidak ada rak sepatu sehingga berantakan, dan menurut wawancara dengan Ibu Wiwi, sering siswa kelas atas yang sengaja jahil menukar-nukarkan sepatu kiri dengan kiri, sehingga membuat siswa tidak mau lagi menaruh diluar.

Berdasarkan wawancara dengan Guru Agama, bahwasannya shalat dhuha dimushola jauh lebih baik dari pada diruangan kelas, alasannya sebagai berikut.

"Kalau di mushola siswa lebih terkontrol, wudhu Saya bisa lihat satu persatu. Kalau sudah, Saya suruh pakai sarung \& kopeah, dan perempuannya pakai mukena. Sekarang mah susah untuk menerapkannya, Sayanya juga keder disini penuh anak-anak dan tidak berbaris, apalagi Saya solatnya sendiri selama di ruangan kelas. Kalau disana luas, saya juga bisa shalat." (Narasumber Guru Agama, Ibu Wiwi Wihartini, M.Pd., 15/11 /2018).

Sarana yang baik untuk pelaksanaan shalat dhuha, tentu di mushola, karena memang mushola pada dasarnya merupa-kan tempat yang didesain untuk melakukan ibadah. Namun, karena yang ditemukan peneliti adanya kurang komunikasi yang baik antara pihak DKM dengan pihak sekolah sehingga pelak-sanaan shalat dilakukan diruangan kelas dan di perpustakaan. Padahal berdasarkan wawancara dengan DKM alMuwaddah Bapak Drs. Abdul Karim, M.Ag., beliau membolehkan untuk shalat namun dengan syarat mushola harus tetap dalam keadaan bersih setelah digunakan shalat oleh siswa. Salahnya, pihak sekolah sampai saat ini $(22 / 11 / 2018)$ tidak datang ke sini (rumah bapak Drs. Abdul Karim, M.Ag) untuk membahas persoalan ini.

3. Evaluasi pembelajaran agama melalui pembiasaan shalat dhuha di SDN Mega Eltra

Evaluasi pembelajaran agama melalui pembiasaan shalat dhuha dilakukan melalui kegiatan pemantauan, supervisi, pelaporan, dan tindak lanjut secara berkala dan berkelanjutan, setidaknya sebulan sekali. Pengawasan proses pembelajaran dilakukan oleh kepala sekolah dan guru agama. Supervisi yang dilakukan di SDN Mega Eltra dilakukan secara berkala oleh kepala sekolah dan guru agama sebagai sistem pengawasan internal. Supervisi proses pembelajaran dilakukan pada tahap perencanaan, pelaksanaan, dan penilaian hasil pembelajaran yang dilakukan melalui antara lain, pemberian keteladanan, diskusi, dan nasehat langsung terhadap siswa.

\section{E. Pembahasan}

Perencanaan pembelajaran agama melalui pembiasaan shalat dhuha SDN Mega Eltra dilakukan sebelum pembelajaran dimulai melalui penyusunan kurikulum yang didiskusikan dalam rapat, sehingga bisa mencapai tujuan pembelajaran yang diharapkan. Pernyataan tersebut sejalan dengan Kaufman dalam Harjanto (2006: 2) yang menjelaskan bahwa perencanaan ialah suatu proyeksi mengenai apa yang dibutuhkan untuk 
mencapai tujuan yang benar dan bernilai.

Dengan adanya perencanaan yang baik maka hasil ataupun kegiatan pembelajaran akan berjalan sejalan tujuan dengan baik. Hal ini pun juga selaras dengan penjelasan G.R. Terry dalam bukunya Principle of Management (1995: 17) mendefinisikan perencanaan (planning) sebagai berikut, "planning is the selecting and relating of facts and the making of using of assumptions regarding the future in the visualization and formulations of proposed activities believed necessary to achieve desired results".

Penerapan agama melalui pembiasaan shalat dhuha SDN Mega Eltra sudah baik. Hal ini menjadi pembiasaan yang baik dan berhasil diterapkan di lingkungan sekolah. Sesuai dengan teori behavioristik yang dicetuskan oleh John. B Watson dan yang digerakkan oleh Burrhus Frederic Skinner dalam Sobur (2013: 123), bahwasannya manusia akan berkembang berdasarkan stimulus yang diterimanya dari lingkungan sekitarnya. Lingkungan yang buruk akan menghasilkan manusia buruk; lingkungan yang baik akan menghasilkan manusia baik. Pandangan ini berasumsi bahwasannya apa yang terjadi pada seseorang salah satunya yang menentukan adalah lingkungannya.

Di SDN Mega Eltra telah menciptakan lingkungan pembiasaan shalat dhuha satu minggu sekali dimana setiap ada mata pelajaran agama dan berhasil membuat siswa terbiasa dan rutin melaksanakan shalat dhuha. Hal ini jelas terbukti bahwasannya teori behavioristik dapat dibenarkan karena berdasarkan penelitian teori behavioristik mampu terbukti membuat siswa menjadi manusia yang baik dari sebuah pembiasaan yang diciptakan di lingkungan sekolah, yaitu pada lingkungan yang mencerminkan lingkungan yang baik (sekolah) dan menghasilkan manusia baik (menjadi siswa-siswi yang berakhlak mulia dengan melaksanakan shalat sunnah dhuha).

Kurangnya kebersihan tempat ibadah akan mempengaruhi adanya peluang najis yang mengakibatkan shalat dhuha menjadi batal. Menurut Muhammad (2009: 5) bahwasannya syarat syah shalat adalah salah satunya dari segi tempat shalat, yaitu mengatakan bahwa shalat wajib mengeluarkan najis dari tiga hal, dari tubuh seseorang, dari pakaian seseorang, dan dari tempat shalat. Dalil tentang kesucian tempat shalat berdasarkan firman Allah swt yang artinya: "bersihkanlah rumah-Ku (Baitullah) (wahai Ibrahim dan Ismail) untuk orang-orang yang thawaf, yang i'tikaf, yang ruku', dan yang sujud." (al-Baqarah: 125). Sehingga wajib adanya membersihkan sarana tempat ibadah yang akan dilaksanakan untuk shalat dhuha walau dilingkungan kelas atau perpustakaan.

Berdasarkan hadits berikut yang artinya: "sebagaimana diberitahukan Abu Sa'id al-Khudri "Tatkala Rasulullah sedang shalat bersama sahabat-sahabat beliau, tiba-tiba beliau melepas kedua sandalnya lalu meletakkan disebelah kiri beliau. Ketika melihat hal tersebut mereka (para sahabat) pun melepas sandal mereka. Selesai dari shalat, Rasulullah bertanya "Ada apa kaian melepas sandal-sandal kalian?" Mereka menjawab, "Kami melihatmu melepas sandalmu maka kami pun melepas sandal-sandal kami." Rasulullah menjelaskan, "tadi Jibril mendatangiku dan mengabarkan bahwa pada kedua sandalku ada kotoran/najis, maka aku melepaskan keduanya." Beliau juga mengatakan, "Apabila salah seorang dari kalian datang ke masjid, sebelum masuk masjid hendaklah ia melihat kedua sandalnya. Bila ia lihat ada kotoran atau najis maka hendaklah 
membersihkannya. Setelah bersih, ia boleh shalat dengan menggunakan kedua sendalnya." (HR. Abu Dawud No. 650).

Berdasarkan hadits tersebut bahwa di SDN Mega Eltra masih belum dilaksanakan secara baik mengenai sarana tempat ibadah di ruangan kelas. Terlihat dengan masih banyaknya sisasisa tanah yang ada disekeliling sepatu yang ditaruh di dalam kelas dan ditaruh diluar kelas. Sayangnya fungsi keset yang ada untuk mengelap alas kaki menjadi beralih fungsi yaitu sebagai alas tempat sepatu (beberapa sepatu), hal ini menjadikan alas kotor ketika memasuki wilayah kelas yang dijadikan sebagai tempat shalat.

Penerapan agama melalui pembiasaan shalat dhuha di SDN Mega Eltra yang kami temukan memang tidak berbanding lurus dengan pembiasaan siswa. Maksudnya, pembiasaan siswa dalam pelaksanaan shalat dhuha sudah bagus, karena dilaksanakan efektif setiap hari dimana terdapat mata pelajaran agama, bahkan ketika tidak ada air pun siswa melakukan tayamum karena mereka merasa ada sesuatu hal yang kurang ketika tidak melaksanakan shalat dhuha dimana terdapat mata pelajaran agama, namun tidak didukung dengan sarana dan prasarana yang memadai.

Dengan tidak lagi digunakannya mushola warga untuk kegiatan ibadah shalat dhuha siswa-siswi SDN Mega Eltra, pihak sekolah mengantisipasi hal ini dengan melaksanakan shalat di ruangan kelas, bahkan terkadang dilaksanakan di perpustakaan, walau pada dasarnya memang kurang kondusif, namun setidaknya pelaksanaan pembiasaan ini akan tetap berjalan, mengingat banyaknya nilai dan dampak positif yang dilahirkan ketika setelah melakukan shalat dhuha sampai sekarang. Namun sayangnya, kebersihan ketika ingin melaksanakan shalat dhuha sendiri kurang diperhatikan, karena masih banyak sisasisa tanah yang terbawa oleh alas sepatu siswa-siswi yang yang dibawah meja yang mengakibatkan area untuk shalat dhuha masih kotor; dan masih berserakan sepatunya didepan kelas dan banyak tanah disekelilingnya; juga beralih fungsinya keset menjadi alas untuk menyimpan sepatu didepan kelas, sehingga ketika keset ditaruh di kelas dan siswa mengusapkan alas kakinya setelah wudhu, maka akan kotor kakinya dan mengenai lantai yang nantinya akan diinjak oleh siswa-siswi lain, alhasil menempel pada sejadah dan peluang terkena najis akan semakin besar. Namun setelah peneliti memberikan solusi yaitu rak sepatu dan keset, tempat ibadah shalat dhuha dilaksanakan di perpustakaan yang ruangannya lebih besar dan kondusif untuk shalat sunnah dhuha, dan bersih tidak ada sisa-sisa tanah yang terbawa oleh sepatu karena tidak digunakan pada kegiatan pembelajaran, dan sepatu disimpan di rak yang telah disediakan dan keset pun dipergunakan dengan sebagaimana mestinya.

Sementara itu, pengawasan pembelajaran agama melalui pembiasaan shalat dhuha dilakukan dengan prinsip transparan dan objektif untuk peningkatan mutu secara berkesinambungan. Hal ini sejalan dengan teori Hikmat (2011: 137) yang menjelaskan bahwa supervisi sangat berkaitan dengan fungsi directing atau commanding dalam mengendalikan penyeleng-garaan organisasi relevan dengan kebijakan dan ketentuan yang sudah ditetapkan, sehingga bisa menjamin berlangsungnya implementasi pembelajaran agama.

Fenomena yang terjadi di SDN Mega Eltra bahwa supervisi yang dilakukan memang sebagian telah relevan dengan Permendiknas Nomor 65 Tahun 2013 mengenai standar proses pembelajaran bahwa supervisi yang 
dilakukan telah mencakup perencanaan, pelaksanaan, dan penilaian pembelajaran. Peneliti menganggap bahwa dengan adanya pengawasan dan supervisi yang intensif di sekolah, baik yang dilakukan oleh kepala sekolah ataupun guru agama akan berdampak baik terhadap pelaksanaan pembelajaran agama melalui pembiasaan shalat dhuha dalam menerapkan manajemen pembe-lajaran baik dari perencanaan, pelaksanaan, dan evaluasi pembelajaran agama.

\section{F. Kesimpulan}

Manajemen pembelajaran agama melalui pembiasaan shalat dhuha di SDN Mega Eltra sudah terlaksana dengan baik. Perencanaan dilakukan melibatkan seluruh guru dan pimpinan sekolah. Pelaksanaan terlihat dari para selalu melaksanakan shalat dhuha ketika terdapat mata pelajaran Pendidikan Agama Islam dari tahun 2015. Namun masih kurang diperhatikan dalam sarana tempat ibadahnya. Terlebih mushola warga tidak digunakan lagi karena setelah dipakai shalat oleh siswa-siswi menjadi kotor, sehingga sarana tempat ibadahnya di kelas masing-masing, ini pun tidak dijaga kebersihannya karena masih banyak penataan sepatu dan keset yang tidak tepat sehingga mengotori wilayah tempat ibadah. Sehingga hal ini dapat diantisipasi dengan cara menerapkan pola kebersihan dengan membersihkan lantai baik menyapu dan mengepel sebelum akan melaksanakan shalat dhuha; dan menyimpan sepatu di rak sepatu (diluar kelas), dan menggunakan keset sebagai alat untuk mengusap alas kaki sebelum memasuki ruangan kelas atau perpustakaan yang dijadikan tempat shalat. Dengan demikian penerapan agama melalui shalat dhuha di SDN Mega Eltra semakin baik. Evaluasi senantiasa dilakukan secara berkelanjutan oleh kepala sekolah dan guru agama.

\section{Daftar Pustaka}

Adil, Sa'id. 2006. Fiqhun Nisa. Bandung: PT Mizan Logika.

Bafadhal. 2004. Perencanaan Pengajaran Berdasarkan Pendekatan Sistim. Jakarta: PT Bumi Aksara.

Harjanto. 2006. Perencanaan Pembelajaran. Jakarta: Rineka Cipta.

Hawary, Hasnan Amin. 2015. Kebiasaan Shalat Dhuha dan Peranannya terhadap Prestasi Belajar Siswa Kelas VII SMP Muhammadiyah PAKEM. Yogyakarta: Universitas Islam Negeri Sunan Kalijaga.

Hikmat. 2011. Manajemen Pendidikan. Bandung: Pustaka.

Husna, Asmaul. 2015. Pembiasaan Shalat Dhuha Sebagai Pembentukan Karakter Siswa Di MAN Tlogo Blitar Tahun Ajaran 2014/2015. Skripsi.

Jamin, Rohan Abu. 1992. Shalat Tiang Agama. Jakarta: Media Da'wah

Kurniawan, Asep. 2018. Metodologi Penelitian Pendidikan. Bandung: Rosdakarya.

Miles, B. Mathew \& Michele Huberman. 1992. Analisis Data Kualitatif Buku Sumber tentang Metode-Metode Baru. Jakarta: UIP.

M. Khalilurrahman Al-Mahfani. 2008. Berkah Sahalat Dhuha. Jakarta: PT Wahyu Media.

Moh, Rifa'i. 1976. Risalah Tuntunan Shalat Lengkap. Semarang: PT Karya Toha Putra.

Shofia, Abu. 2003. Amalan Shalat Sunnah dan Keutamannya. Surabaya: Karya Agung.

Sholeh, Moh. 2013. Pembiasaan Shalat Dhuha dalam Pembinaan Akhlak Siswa Kelas 4 MI Ma'arif Candran Yogyakarta. Yogyakarta: Universitas Islam Negeri Sunan Kalijaga.

Subagyo. 2016. Pembinaan Akhlak melalui Pembiasaan Shalat Dhuha di Sekolah Luar Biasa Negeri 
Purbalingga. Purwokerto: Institut Agama Islam Negeri Purwokerto

Sugiyono. 2003. Metode Penelitian Bisnis. Bandung: Alfabeta.

Sobur, Alex. 2013. Psikologi Umum dalam Lintasan Sejarah. Bandung: CV Pustaka Setia.

Syaikh, Muhammad bin Abdul Wahhab. 2009. Syarat-Syarat Rukuk dan Kewajiban dalam Shalat. Maktabah Raudhah al-Muhibbin.
Syaikh Mu'min Al-Hadadd. 1998. Jama'ah Mabruro. Jakarta: Wawasan Pengetahuan.

Terry, George R.. 1995. Principles of Management. Illinois: Homewood, Ill.: R.D. Irwin.

Zezen, Zainal Alim. 2008. The Power Of Sholat Dhuha. Jakarta: Quantum Media. 